\title{
Behavioral Ethics: Toward a Deeper Understanding of Moral Judgment and Dishonesty
}

\section{Citation}

Bazerman, Max, and Francesca Gino. "Behavioral Ethics: Toward a Deeper Understanding of Moral Judgment and Dishonesty." Annual Review of Law and Social Science 8 (2012): 85-104.

\section{Published Version}

http://www.annualreviews.org/doi/abs/10.1146/annurev-lawsocsci-102811-173815

\section{Permanent link}

http://nrs.harvard.edu/urn-3:HUL.InstRepos:10996807

\section{Terms of Use}

This article was downloaded from Harvard University's DASH repository, and is made available under the terms and conditions applicable to Open Access Policy Articles, as set forth at http:// nrs.harvard.edu/urn-3:HUL.InstRepos:dash.current.terms-of-use\#OAP

\section{Share Your Story}

The Harvard community has made this article openly available.

Please share how this access benefits you. Submit a story.

Accessibility 
RUNNING HEAD: Behavioral Ethics

\author{
Behavioral Ethics: \\ Toward a Deeper Understanding of Moral Judgment and Dishonesty
}

Max H. Bazerman

Francesca Gino

Harvard Business School

Forthcoming, Annual Review of Law and Social Science

Corresponding author:

Max H. Bazerman

Harvard Business School

Baker Library 453

Soldiers Field Road

Boston, MA 02163 USA

Telephone: (617) 495-6429

Fax: (617) 496-4191

Email: mbazerman@hbs.edu 


\begin{abstract}
Early research and teaching on ethics focused on either a moral development perspective or philosophical approaches, and used a normative approach by focusing on the question of how people should act when resolving ethical dilemmas. In this paper, we briefly describe the traditional approach to ethics and then present a (biased) review on the behavioral approach to ethics. We define behavioral ethics as the study of systematic and predictable ways in which individuals make ethical decisions and judge the ethical decisions of others that are at odds with intuition and the benefits of the broader society. By focusing on a descriptive rather than a normative approach to ethics, behavioral ethics is better suited than traditional approaches to address the increasing demand from society for a deeper understanding of what causes even good people to cross ethical boundaries.
\end{abstract}

Keywords: Morality; Ethical Decision Making; Corruption; Behavioral Decision Research; Unethical Behavior 


\section{Table of Content}

Introduction $\quad \ldots 4$

I. Pre-behavioral Business Ethics $\quad \ldots 5$

II. The Emergence of Behavioral Ethics $\quad \ldots 9$

II.1 Intentional Dishonesty: Predictable but Surprising Unethical Behavior $\quad \ldots 13$

II.2 Moral credentials, Moral resentment and Moral hypocrisy $\quad \ldots 18$

II.3 Unintentional Dishonesty: The Case of Bounded Ethicality $\quad \ldots 21$

III. Improving Ethics by Using a Behavioral Ethics Perspective $\quad \ldots 26$

III.1 Changing Individual Morality $\quad \ldots 26$

$\begin{array}{ll}\text { III.2 Changing Policy } & \ldots 29\end{array}$

$\begin{array}{ll}\text { References } & \ldots 33\end{array}$

$\begin{array}{ll}\text { Figure Captions } & \ldots 42\end{array}$

Tables $\quad \ldots 43$

$\begin{array}{ll}\text { Figures } & \ldots 44\end{array}$ 


\section{Behavioral Ethics:}

\section{Toward a Deeper Understanding of Moral Judgment and Dishonesty}

Professionals across industries sometimes engage in unethical action, as demonstrated by scandals at Enron and other major corporations in the early 2000s, the Ponzi scheme by Madoff, the worldwide financial crisis and, even more recently, the Murdoch newspaper scandal in mid2011. Partly due to the significant costs that these behaviors inflicted on a large number of individuals, these and related cases of organizational corruption and dishonest behavior have led society to demand action from professional schools. These demands started to increase exponentially with the Enron debacle, and the growth continues. As business school professors, we are disappointed with what academics have offered to date in response to these increasingly frequent demands. More importantly, we believe that there are limitations to the strategies used in our efforts as academics to respond, and believe that there are more effective ways that can help reduce ethical failures in both business and society more broadly in the future.

In this review, we first define business ethics and then provide our (biased) history of the attempts of professional schools to address ethics as a subject of both teaching and research. We then present a short summary of the emergence of the field of behavioral ethics over the last two decades. Next, we turn to recent research findings in behavioral ethics that we believe can provide helpful directions for a social science perspective to ethics. We suggest that these new findings on both intentional and unintentional unethical behavior can inform new courses on ethics, provide guidance in the policy formation process, as well as suggesting new research directions. Such new directions can meet the demands of society more effectively than our past 
attempts, and we believe they can produce a meaningful and significant change in the behavior of both business schools students and professionals.

\section{Pre-behavioral Business Ethics}

Prior to the 1990s, it was rare for professional schools to have a significant focus on the area of ethics (or business ethics more specifically) in the courses offered to students. Ethics was not well accepted by professional schools as a core topic for teaching and research, and fell into the bucket of other topics like international business and the natural environment, topics explored by a few isolated professors. When schools had courses on ethics or scholars doing research in this domain, the topic was typically in the hands of philosophers. The information conveyed in the classroom often took the approach of helping students recognize different philosophical traditions for understanding what constituted an ethical decision. And, the delivery was mainly informational rather than experiential.

For the most part, scholars adopted a prescriptive or normative approach that used insights from philosophy to describe how moral and ethical people should behave (Treviño \& Weaver, 1994). Ethics was generally focused on the evaluation of actions from a moral point of view, in an attempt to answer how people should behave. Similarly, business ethics was focused on the evaluation of practices of employees, managers and their organizations from a moral standpoint (Ferrell, Fraedrich, \& Ferrell, 2008). This approach stressed the role of cognitive development and process stages involved in moral deliberation. For instance, expanding upon Piaget's three-stage framework of cognitive development, Kohlberg (1981) suggested that ethical behavior is determined by the sophistication of a person's moral reasoning. Kohlberg proposed that moral judgment develops through a sequence of three levels, which are comprised of two stages at each level, resulting in six stages. Although individuals who have reached 
advanced stages may occasionally reason at a lower level, the central tenet of Kohlberg's model is that people at more developed stages make superior moral decisions than those at earlier stages (Gibbs, Basinger, \& Fuller, 1992; Rest \& Navarez, 1994). Similarly, another commonly discussed process was proposed by Rest (1986), and consisted of four steps: awareness, judgment, intention, and behavior. In this model, success at one stage does not imply success at subsequent stages. Thus, according to Rest's (1986) theorizing, decision makers may possess moral judgment but because they fail to establish moral intent in one context they engage in unethical behavior. Thus, across these various models, the moral development approach to ethics we have discussed highlights the role and impact of individual traits in explaining unethical behavior by suggesting that morality is a rather stable personality trait that individuals develop by going through differences phases of development.

In addition to learning about these cognitive approaches to moral development, students were often taught the various distinctions and debates that had existed in philosophy for centuries and that were still unresolved. For example, one such distinction was between two different normative approaches to ethical decision-making: a utilitarian and a deontological approach. Utilitarianism examines moral actions from the perspective of the results that flow from ethical decisions and is often described by the phrase "the greatest good for the greatest number of people." In contrast, the philosopher Immanuel Kant (1724-1804) argued for the use of a deontological approach, according to which the morality of an action is judged based on the action's adherence to rules or principles. In this view, judgments of right or wrong are determined by the motives of the person who acts, not based on the consequences of the person's actions. To demonstrate the distinction between these two approaches and examine when people 
tend to use them, scholars often employ the so-called "trolley/footbridge problems." The trolley

problem is commonly described as follows (see Figure 1 for a depiction of this problem):

A runaway trolley is headed for five railway workmen who will be killed if it proceeds on its present course. The only way to save these people is to hit a switch that will turn the trolley onto a side-track where it will run over and kill one workman instead of five. Ignoring legal concerns, is it ethically okay to turn the trolley in order to save five people at the expense of one?

When facing this problem, most people report that it is okay to switch, and explain their choices

by reasoning that having five people die is worse than having one person die (Greene, 2012).

This answer follows directly from a standard utilitarian analysis. The footbridge problem is a

variation of the trolley problem, and it is commonly described as follows (see Figure 2 for a

depiction of this problem):

A runaway trolley threatens to kill five people. You are standing on a footbridge spanning the tracks next to a railway worker wearing a large backpack, in between the oncoming trolley and the five people. The only way to save the five people is to push this man off the bridge and onto the tracks below. The man will die as a result, but his body will stop the trolley from reaching the others. (You can't jump yourself because you don't have enough weight on you to stop the trolley, and there's no time to put the backpack on.) Ignoring legal concerns, is it okay to save the five people by pushing this stranger to his death?

In this case, most people are against pushing the person, and explain their choices by providing reasons that are consistent with a deontological approach (Kant, 1724-1804). Thus, they attempt to apply rules to determine the morally appropriate act. In fact, when prompted to provide reasons for their choices, people commonly mention reasons such as "it's murder!", “the ends don't justify the means!" or "people have rights!” (Greene, 2012). Through the use of these problems, philosophers demonstrated an apparent inconsistency in the response people provide when facing ethical dilemmas (Foot, 1978; Thomson, 1976; for detailed review, see Greene, 2012). From a theoretical perspective, traditional philosophers are still debating about whether a utilitarian or a deontological logic is more appropriate to solve ethical dilemmas like these 
problems. From an empirical perspective, the data allow scholars to move away from this debate and move towards the study of the conditions under which people are likely to use one approach rather than the other in solving ethical dilemmas.

When the utilitarian and the deontological approaches are discussed in ethics courses, professors commonly highlight the distinction between them, have students discuss it and argue for their own view. As in the case of classes focusing on cognitive approaches of moral development, we believe that discussing these theories is insufficient for helping students understand how they solve ethical dilemmas and it is also insufficient if we are interested in improving ethicality in professional organizations. This conclusion is shared not only by psychologists and behavioral decision scientists like us but also by philosophers who use an experimental approach to study morality. These experimental philosophers (often referred to as “x-phi”; e.g., Greene, 2012; Knobe, 2003; see also Knobe \& Nichols, 2008) are viewed with great controversy in philosophy since they conduct experiments to learn about what people actually do and say when faced with moral dilemmas. We consider these philosophers to be part of what we define here as behavioral ethics.

Philosophers have argued that philosophical thinking is central to moral education, will make us better citizens and will also provide the courage to stand up for justice (Schwitzgebel, 2009). Yet, Posner (1997) argues that there is no empirical evidence in support of these claims. Experimental philosopher Schwitzgebel (2009) notes that most people expect ethicists to behave more ethically since they devote their careers to studying and teaching morality. Yet, this belief is not supported by empirical evidence: if morality is equated with not stealing, ethicists do not score so well (Schwitzgebel, 2009). Using data from thirty-one leading academic libraries in the United States and in the United Kingdom, Schwitzgebel (2009) found that ethics books were 
more likely to be missing than non-ethics books in philosophy that were comparable in age and popularity. Further, obscure texts that were likely to be borrowed only by advanced students and professors of ethics were about 50 to $100 \%$ more likely to be missing, depending on the specific measure used in the analyses. Although these results may seem surprising, they can be easily explained if we consider that normative ethicists have primarily focused on examining how people should think about behavior in the ethics domain. We do not intend to minimize their work: from a normative perspective, ethicists have made enormous contributions in clarifying answers to these types of questions. It is also worth noting that the normative tone that is inherent in this literature is reflected in most codes of conduct and moral guidelines issued by management in organizations (Adams, Taschchian, \& Shore, 2001; Weaver, 2001). However, as a result of the field's approach, up until recently, little empirical attention has been given to how people actually behave or to how their behavior can be improved.

This focus on how human beings actually behave in moral contexts is where the new behavioral ethicists have found their niche. Behavioral ethicists describe the actual behavior of people, how situational and social forces influence it, and they study ways in which decisions can be nudged in a more ethical direction through simple interventions. This new approach to ethics requires understanding and explaining moral and immoral behavior in systematic ways. It requires understanding the antecedents and consequences of both ethical and unethical actions. Finally, it requires identifying levers at both the individual and the institutional level to change ethically questionable behaviors when individuals are acting in unethical ways that they would not endorse with greater reflection. In the remainder of this paper, we review these recent approaches to ethics. We note that, throughout the paper, we will use immoral, unethical, and dishonest as interchangeable. 


\section{The Emergence of Behavioral Ethics}

Scholars in behavioral ethics define their field of study differently (see Table 1 for definitions of behavioral ethics and ethical behavior by different authors doing research on the topic). At a very broad level, many social scientists have been developing knowledge about the determinants of ethical and unethical behavior, and have started from the assumption that even good people sometimes do bad things (see Bersoff, 1999). Scholars such as Brief (e.g., Brief \& Motowidlo, 1986) and Treviño (1986) have been working on this topic long before others like us took up the task. We note that a often separate stream of research, born out of the traditional philosophical approaches to ethics, has focused on the understanding of how people form moral judgments and what factors influence them (see, for instance, Cushman, \& Young, 2012; Haidt, 2001; Pizarro, Inbar, \& Helion, 2011; Uhlmann, Pizarro, Tannenbaum, \& Ditto, 2009).

While we do not dispute the existing definitions for behavioral ethics, we seek to provide a definition that focuses more closely on the psychology of individuals and the biased decisions and judgments they make systematically. Because of its focus on individuals' actual judgments and behavior, behavioral ethics draws heavily from psychology and behavioral decision research and advocates a descriptive rather than a normative approach to the study of ethics.

With this in mind, we define behavioral ethics as the study of systematic and predictable ways in which individuals make ethical decisions and judge the ethical decisions of others that are at odds with intuition and the benefits of the broader society. As this definition suggests, we are interested in examining not only the decisions that people make, but also their judgments of the decisions of others. We are also interested in examining the systematic ways in which humans depart from our intuitive expectations and the goals of the broader society. 
One of the early efforts in what we see as the start of the behavioral ethics movement was the publication of an edited volume by Messick and Tenbrunsel (1996). This was the earliest example of a publication that clearly organized and beautifully explained what we knew about the psychology of ethics. Many of the papers in this volume highlighted counterintuitive ways in which people make decisions and form judgments in the domain of ethics. One of the papers that is particularly relevant for the approach we are proposing here is Loewenstein's (1996) chapter on how behavioral decision theory helps us understand ethical decisions. Behavioral decision theory is commonly defined as the study of trade-offs that people make when deciding what to choose among the options available to them. For example, a person choosing which car to buy may trade off a low price for one car against the well-respected brand name of the second car. Ethical decisions commonly involve trade-offs between the decision maker's well-being (e.g., not risking losing a job for blowing the whistle) and that of others (e.g., creating harm to potential consumers by not stopping the production of an unsafe product). Thus, as suggested by Lowenstein (1996), by using behavioral decision theory we can better understand how people resolve ethical dilemmas and make ethical decisions. Similar to Lowenstein's (1996) arguments, Bazerman and Banaji (2004, p. 1150) noted "that efforts to improve ethical decision making are better aimed at understanding our psychological tendencies." We concur with these views and suggest that understanding people's psychology when they face decisions in the ethics domain is fundamental to the understanding of why good people sometimes do bad things.

In a related paper to this research, Messick and Bazerman (1996) organized some of this early knowledge by identifying three types of theories that individuals use in making decisions: theories about the world, theories about other people, and theories about ourselves. Theories of the world dealt with the beliefs that we hold about the way the world works, expectations about 
causal networks in which we live, and the ways in which our choices influence the world around us. Theories of other people referred to beliefs that we have about how we are different from them. Finally, theories of ourselves dealt with the erroneous or unrealistic beliefs about ourselves that may cause us to take more than our fair share of the credit for success or too little blame for failure. These theories also discussed how we are often too confident that our theory of the world is the correct one. Using this framework, Messick and Bazerman (1996) identified research from social psychology that can inform us about these theories as we attempt to understand ethical decision making.

This early work by Messick and colleagues reviewed a variety of specific findings in social psychology and behavioral decision research and explained their relevance to the study of ethics. We believe that the core contribution of this research was to focus early behavioral ethics on the psychological tendencies that lead even good people to use information and make decisions in ways that lead them to behave unethically, even when they would not expect to behave that way in advance. Messick and colleagues also were critical to broadening the focus of the field to include descriptive work, and more importantly, aspects of behavior that were not the result of deliberative action.

In the remainder of this review, we will retain this focus on psychological aspects that lead people astray in the ethics domain. Using this focus, we will describe two recent streams of research in behavioral ethics in detail. First, we will explore the predictable situational and social forces that can lead people to engage in unethical behavior. In this section of the review, we will focus on behaviors that the actors know to be wrong, but they are unaware of the forces that are leading them to cross ethical boundaries (intentional unethical behavior). Second, we will turn to the recent work on bounded ethicality, which describes the tendency of individuals to 
engage in unethical action without even knowing that they are doing so (unintentional unethical behavior).

Departing from the belief that unethical behavior can be explained by the stage of moral development that the decision maker has reached and by focusing on a descriptive rather than normative approach to ethics, these streams of behavioral ethics research share two empirically supported assumptions. First, they propose that morality is dynamic and malleable, rather than being a stable trait characterizing individuals. Second, they argue that most of the unethical behavior we observe in organizations and society more broadly is the result of the actions of several individuals who, although they value morality and want to be seen as ethical people, regularly fail to resist the temptation to act dishonestly or even fail to recognize that there is a moral issue at stake in the decision they are making.

\subsection{Intentional Dishonesty: Predictable but Surprising Unethical Behavior}

Scholars interested in the study of intentional unethical behavior argue that situational and social forces overwhelm individual differences in explaining ethical behavior. Early wellknown experiments support this argument. For instance, in the famous Milgram's experiment (Milgram, 1974), an experimental assistant (an accomplice) asked each study participant to play the role of a teacher and administer 'electric shocks' to another participant "the learner" (who, in actuality, was a confederate or experimental assistant) each time the learner made a mistake on a word-learning exercise. After each mistake, the participant was asked to administer a shock of higher voltage which began to result in 'apparent' audibly increasing distress from the learner. Over sixty percent of the study participants shocked their participants-accomplice through to the highest voltage which was marked clearly with potential danger (Milgram, 1974). However, only a few people predicted they would behave in such a manner when asked to imagine the 
situation and predict their behavior. These results suggest that it is not individual character that causes one to inflict great pain on an innocent person, but rather the situation in which an authority demands obedience.

Similarly, in another well-known experiment, the Stanford Prison Experiment (see Zimbardo, 2007), Stanford undergraduates were randomly assigned to be either guards or prisoners in a mock prison setting for a two-week experiment. After less than a week, the experiment was suddenly stopped because the guards were engaging in sadism and brutality and the prisoners were suffering from depression and extreme stress. Normal Stanford students had been transformed merely by the situational conditions created for the experiment.

Both of these studies stress the role of situational influences in producing unethical behavior, and suggests that morality is malleable and dynamic (e.g., Monin \& Jordan, 2009): individuals with certain moral traits, even when they strongly value morality, may not behave consistently across different situations and they may cross ethical boundaries under situational pressures.

Additional evidence for the malleability of morality comes from more recent research examining what people do when they are placed in situations in which they have the opportunity to behave unethically (e.g., by lying about their performance on a task) (see Ayal \& Gino, 2011; Mazar, Amir, \& Ariely, 2008). Rather than focusing on the trade-off between the decision maker's well-being and that of others, this research focuses on a different type of trade-off that involves an intertemporal component and is focused on the self: the long-term desire to be a good and ethical person and be seen as such by others to gain social acceptance, and a more short-term desire to behave in a way that would advance one's self-interest (Mead, Baumeister, Gino, Schweitzer, \& Ariely, 2009; Gino, Schweitzer, Mead, \& Ariely, 2011). 
To make this trade-off salient to individuals, the paradigms used in laboratory studies in the research on intentional unethical behavior commonly involve anonymity and no probability of being caught. For instance, in one of the paradigms used in this research (see Gino, Ayal, \& Ariely, 2009), participants are invited to the lab and are asked to complete a problem-solving task under time pressure. The task involves solving 20 different add-to-ten problems, like the one depicted in Figure 3. For each problem, the participants' task is to find the two numbers that sum up to ten, circle them and then move onto the next problem. For each correctly solved problem, participants receive a financial bonus, like 50 cents or a dollar. In the simplest version of this paradigm, in one condition participants are given four or five minutes to work on twenty problems (all variations of the problem depicted in Figure 3). Once the time is over, they fill out a collection slip where they report their performance and then have the experimenter check their work (control condition). In the experimental condition, participants are asked to self-report their performance on the collection slip and then shred their test sheet using a real shredder (shredder condition). The performance participants self-report in the shredder condition is generally much higher than the performance reported in the control condition suggesting that participants cheated by lying about their performance on the problem-solving task so that they would receive a higher payment (see Gino et al., 2009). Scholars have also used variations of this paradigm so that they could track whether each participants cheated and by how much in the treatment condition. Alternatively, scholars have used other types of ability-based tasks where they gave participants the opportunity to cheat by overstating their performance on the task (e.g., Schweitzer et al., 2004; Gino \& Pierce, 2009).

When conducting this research, scholars have often compared the predictions that would derive from a strict traditional, standard economic approach to the predictions that would derive 
from a social psychology perspective. For instance, in the simple experiment described above (comparing performance in the control and shredder conditions), standard economic theory would predict cheating to the maximum extent by most if not all participants in the shredder condition: in fact, the cost of behaving unethically are very low since there is no risk of being caught in this condition. A social psychology perspective, in contrast, would predict little cheating since by lying about their performance only by a little bit, participants in the shredder condition can still benefit from cheating without the need for them to revise their moral selfimage (see Mazar et al., 2008). The results of recent research on intentional unethical behavior are consistent with the social-psychology perspective rather than the standard economic one, providing further evidence for the importance of studying the psychology of individuals in order to understand how they make ethical decisions.

Given the role individuals' psychology plays in explaining unethical behavior, further work has started examining the situational and social forces that influence how people resolve ethical dilemmas and make ethical decisions (for recent reviews, see Ayal \& Gino, 2011, and Shu, Gino, \& Bazerman, 2011). Generally, this research has found that the more room a situation provides for people to be able to rationalize their behavior, the more likely they are to behave unethically (e.g., Gino \& Ariely, 2012; Schweitzer \& Hsee, 2002; Shalvi et al., 2011).

The environment in which people operate activates explicit or implicit norms that, in turn, influence the tendency to cross the ethical line. Cialdini, Reno and Kallgren (1990), for example, found that the amount of litter in an environment activates norms prescribing appropriate or inappropriate littering behavior in a given setting and, as a result, regulates littering behavior. Related research has found that the presence of graffiti leads not only to more littering but actually more theft (Keizer, Lindenberg, \& Steg, 2008), and abundance of resources 
lead to increased unethical behavior (Gino \& Pierce, 2009). In fact, even more subtle situational factors, like darkness in a room, have been found to lead to increased dishonesty (Zhong, Bohns, \& Gino, 2010). Taken together, these studies suggest that visual stimulation from the environment or its physical features can produce profound changes in behavior surrounding ethical and social norms. Like the experiment by Milgram and Zimbardo, these studies focused on situational factors leading people to cross ethical boundaries, and demonstrated that people fail to predict the influence of such subtle factors on their behavior.

Related work focused on social rather than situational factors and found that the actions of other people can influence our own in the ethics domain. Gino and her colleagues (Gino et al., 2009; Gino \& Galinsky, 2012) have shown that our moral behavior is affected by the moral actions of just one other person. Gino, Ayal, and Ariely (2009) found that when people are exposed to an in-group member's unethical behavior, they align with the behavior and behave dishonestly themselves. Building on prior work on social norms (Cialdini et al., 1990; Cialdini \& Trost, 1998) and social identity (Tajfel \& Turner, 1986; Tajfel, 1982; Turner, 1982), Gino et al. (2009) explained that the degree to which people are influenced by social norms of dishonesty depends, to some extent, on the relationship between the initiator and the follower. People tend to perceive questionable behaviors exhibited by in-group members (or people who are similar to them) to be more acceptable than those exhibited by out-group members (or people who they perceive as dissimilar). Others' behavior can influence our own even when the bond we share is very labile or subtle. For instance, sharing the same birthday or first name of a person who behaved dishonestly lead us to act unethically as well (Gino \& Galinsky, 2012).

Together, these studies point to surprising inconsistencies between people's desire to be good and moral and be seen as such by others and their actual unethical behavior, and provide 
evidence consistent with the argument that morality is malleable. In addition to these findings, research over the last decade has also identified inconsistencies in moral behavior of the same person across time, and in judgments of moral actins committed by the self versus others. We describe the research conducted on these two types of inconsistencies next, and then turn to work on unintentional unethical behavior.

\subsection{Moral Credentials, Moral Resentment and Moral Hypocrisy}

Monin and Jordan (2009) suggested that at any given moment individuals may answer the question of how moral they are differently. In their own words, (Monin \& Jordan, 2009: 10):

“...people's thoughts and behavior are often guided by a "working" level of moral selfregard that fluctuates from moment to moment according to situational influences. (...) we contend that situations actually can affect aspects of the self-concept and can therefore influence behavior through this mediator, rather than moderate the link between self and behavior."

When individuals decide whether or not to engage in unethical behavior, they consider their previous moral and immoral actions; they keep track of their moral balance between moral credits (past good deeds) and moral debits (past bad deeds) (Nisan, 1991). More specifically, Nisan's moral balance model (Nisan, 1991) suggests that people compute a personal moral balance based on their actions that are morally relevant within a given timeframe, and do not go below their minimum. At any point in time, good deeds raise the balance, and bad ones lower it. Consistent with Nisan's moral balance model (Nisan, 1991), Monin and Miller (2001) conducted experiments in which they found that a prior moral act can license later morally-questionable behavior. In one study, participants were presented with job-selections task. In a first, jobselection task, half of the participants were given the opportunity to select a stellar African American applicant thus establishing non-racist credentials. The other half of the participants were in a control condition and were asked to pick from an all-White applicant pool. Compared 
to participants in the control condition, participants in the Black-candidate condition were more likely to express that a second, unrelated job in a racist police force would be "better suited" for a White person. This second task was designed such that it was attractive for participants to favor a White person. However, this means behaving in a way that feels unethical in a prejudiceconscious society; as a result, participants do not express this preference unless they had been established their non-racist self-image by the first choice -what Monin and Miller labeled a moral credential. Across various studies, Monin and Miller (2001) demonstrated that bolstering people's moral self-image can liberate them to act in less ethically in the future. Recently, these results have also been extended to other moral domains (Jordan, Mullen, \& Murnighan, 2011). Monin and colleagues have also examined how people react to the moral and immoral behavior of others, and found that learning about the behavior of heroes or saints can threaten people's moral self-regard. As a result, people express resentment for these superior others, even though their behavior is clearly stellar and exemplary (Monin, 2007). In one experiment, Monin and colleagues examined reactions to a target individual who refused to express opinions that contradicted their private beliefs. Although neutral judges appreciated this person and rated them positively on various dimensions, participants who had earlier expressed these ideas that contradicted their beliefs and who did so without complaining expressed high levels of disliking for the target (Monin, Sawyer, \& Marquez, 2008). To the eyes of participants who had willingly gone along with the problematic behavior, the exemplary behavior of the target was perceived as a threat to their own moral self-image. Because of this threat, participants derogated the saint.

Finally, research has examined an inconsistency in the way we judge our own unethical actions versus those of others, a tendency called "moral hypocrisy." More precisely, moral hypocrisy refers to people's desire to appear moral without bearing the actual cost of being moral 
(Batson, Kobrynowicz, Dinnerstein, Kampf, \& Wilson, 1997; Batson, Thompson, \& Chen, 2002; Batson, Thompson, Seuferling, Whitney, \& Strongman, 1999). Several studies have found evidence for moral hypocrisy. In one experiment (Batson et al., 1999’s Study 1), participants could assign themselves and another participant to one of two experimental conditions. By assigning themselves to a positive study condition (with the opportunity to win $\$ 30$ ), the other participant was assigned to a neutral condition (no money) and vice versa (assigning themselves to the neutral condition let the other participant be assigned to the positive condition). To make moral standards salient, participants were told that most people consider coin flipping the fairest way to assign conditions. Twenty-eight of the 40 participants chose to flip the coin. Of these, four assigned the other individual to the positive study condition, whereas the remaining 24 assigned themselves to the positive study condition. Clearly they used the coin flip to justify their self-serving decision. Indeed, those who flipped the coin rated their behavior as highly moral, thus providing evidence for moral hypocrisy. More recently, Piovesan, Montinari, Gino and Norton (2012) explored the developmental nature of moral hypocrisy. Specifically, Piovesan et al. (2012) examined whether children become more concerned with behaving more fairly towards others or instead merely concerned with appearing fair over the course of development. Using data from almost 600 children in the age range 6-11, and a paradigm similar to that employed by Batson and his colleagues, Piovesan et al. found that older children were more likely to flip the coin than younger children, but were just as likely as younger children to assign themselves the good prize by reporting "winning" the coin flip more than chance would dictate. These results suggest that moral hypocrisy develops with age.

Although different, all the studies described in this section share a common message: they demonstrate the surprising ways in which we act worse than we would have anticipated 
when we face ethical dilemmas, and they demonstrate inconsistencies in the way we judge unethical behavior depending on whether we or others engaged in it. In all these studies, people generally recognized that they were behaving unethically but they failed to understand why they perceived ethical norms differently or what caused them to act dishonestly. Furthermore, they applied different standards to judge their unethical behavior and that of others.

In addition to these forms of intentional unethical behavior and inconsistencies in moral judgment, recent research has also examined unintentional unethical behavior. We turn to this research next.

\subsection{Unintentional Dishonesty: The Case of Bounded Ethicality}

Imagine that you sell investments to retail customers. You work with a variety of funds to identify investment opportunities for your customers. For years, one of these investments that you have sold to clients has outperformed the market, with a substantial lack of risk - the fund has performed consistently across years, even years when the market was down significantly. The fund is run by a well-respected individual, and your customers are delighted with their returns. How do you think about your decision to recommend this fund? When thinking about this decision, does ethics come to mind?

Maybe a few more details will help. What if we also mentioned that finance experts have argued that you cannot significantly outperform the market with the low volatility of this fund? What if we also mentioned that the S.E.C. had been repeatedly warned that there was a legal problem with the fund? What if we add that the fund was created and run by Bernard Madoff?

While some investment firms that sold Madoff's investments may have been crooks who knew that the fund had problems, we believe that many others never considered the morality or 
legality of the fund. They had defined the problem as an investment decision, and ethics were not even on the radar screen. Thus, the need to assess the ethics of the situation never arose.

As we discussed earlier, ethics is often defined to include intentional deliberation. Rest's (1986) first step is assumed to exist for an ethical problem to exist, i.e., to be morally aware. But, as we suggest in this example and as documented by Tenbrunsel and Messick (2004), the assumption that people are making explicit tradeoffs between behaving ethically and self-interest is not always met -even in cases where we later see a set of unethical actions to have occurred.

Over the last few years, researchers have been documenting the systematic patterns of behaviors in which people act unethically without their own awareness, and fail to notice the unethical behavior around them (Bazerman \& Tenbrunsel, 2011; Chugh, Bazerman, \& Banaji, 2005; Gino, Moore, \& Bazerman, 2009). People engage in behaviors that they would condemn and consider unethical upon further reflection or awareness. That is, they are boundedly ethical. Bounded ethicality takes a variety of forms, including overclaiming credit for group work without realizing that you are doing so, engaging in implicit discrimination and in-group favoritism, over-discounting the future and harming the environment, and failing to realize that you hold overly positive views of yourself (Bazerman \& Moore, 2008; Tenbrunsel, Diekmann, Wade-Benzoni, \& Bazerman, 2011), to name just a few. The literature on implicit attitudes and associations documents how it is that people act in racist and sexist ways without being aware that they are doing so (e.g., Chugh et al., 2005). We also favor in-groups, without awareness of the impact that this will have on out-groups. For example, Messick (1994) argues that mortgage loan discrimination against minorities is much more likely to result from lenders' unconscious favoritism toward in-groups than from explicit hostility toward out-groups. In addition, we overly discount the future, increasing the debt burden or destroying the planet, often without 
awareness that we are acting in ways that may harm future generations (Wade-Benzoni, 1999). More evidence of our ethical inconsistencies comes from Kern and Chugh (2009) who find that our ethical decisions are swayed by the framing of information. Specifically, they show that we are more likely to behave unethically to avoid losses than to obtain gains, even when the differences between whether people are thinking about losses versus gains is based on the framing of the same objective information.

This research has focused on how our ethicality is bounded when we face ethical choices. Related work has examined the many ways in which our ethicality is bounded when we evaluate or judge the behaviors of others from a moral standpoint. This research documents the surprising degree to which people will ignore the unethical actions of others. For example, Moore, Tetlock, Tanlu and Bazerman (2006) show that while we recognize others' conflicts of interest, we fail to recognize conflicts of interest that we ourselves face that leads to corrupt behavior. Thus, when we have a desire not to see the unethical actions of others, we do not, and we commit this failure often without our own awareness. In a similar vein, our joint research (Gino \& Bazerman, 2009) demonstrates that people are more likely to ignore the unethical behavior of others when ethical degradation occurs slowly rather than in one abrupt shift.

Research also shows that we are far more likely to condemn unethical behavior when the behavior leads to a bad rather than a good outcome -even when controlling for the action of the actor being judged (Gino, Shu, \& Bazerman, 2010; Gino, Moore, \& Bazerman, 2012). Cushman and colleagues (Cushman, Dreber, Wang, \& Costa, 2009) asked study participants to choose between the following two options:

Option A: You roll a six-sided die. If it comes up 1-4, you get $\$ 10$, and the other party gets $\$ 0$. If it comes up a 5 , you get $\$ 5$, and the other party gets $\$ 5$. If it comes up a 6 , you get $\$ 0$, and the other party gets $\$ 10$. 
Option B: You roll a six-sided die. If it comes up a 1, you get $\$ 10$, and the other party gets $\$ 0$. If it comes up $2-5$, you get $\$ 5$, and the other party gets $\$ 5$. If it comes up a 6 , you get $\$ 0$, and the other party gets $\$ 10$.

Option A is the greedier choice, as it offers you more opportunities (four out of six, to be exact) to claim \$10 for one. Option B is the "fair" choice, at least most of the time, as it offers four opportunities for the $\$ 10$ to be split evenly between you and the other party. After choosing, the die is rolled, and the money is paid. The other player was then allowed to punish the original decision-maker, without incurring any cost to herself. Consistent with our own research on the topic (see Gino et al., 2010; Gino et al., 2012), when allocating punishment, the other party paid more attention to the equality of the result of the rolled die - a random outcome - than to the chooser's sense of fairness (as demonstrated by which option she chose). This research explains our unfortunate tendency to blame people too harshly for making sensible decisions that have unlucky outcomes.

Another factor that leads us to ignore the unethical behavior of others is the presence of intermediaries. Paharia, Kassam, Greene, and Bazerman (2009) examined individuals' tendency to ignore price gouging, if the gouging occurs through an intermediary. Essentially, Paharia et al. (2009) found that people often ignore the unethical actions of others, if the unethical actor has an intermediary do the dirty work. This work was motivated by a story about Merck selling the rights to two less profitable cancer drugs to a smaller and lesser-known company, Ovation Pharmaceuticals, while raising the price of the drug by 1,000\%. Paharia et al. (2009) reasoned that had Merck raised the price directly, citizens would have responded in a negative, emotional manner. They conducted a series of studies. In one of these studies, Paharia et al. (2009) asked participants to consider the following situation:

A major pharmaceutical company, $\mathrm{X}$, had a cancer drug that was minimally profitable. The fixed costs were high and the market was limited. But, the patients who used the 
drug really needed it. The pharmaceutical was making the drug for $\$ 2.50 /$ pill (all costs included), and was only selling it for $\$ 3 /$ pill.

One group of participants assessed the ethicality of the following action:

A: The major pharmaceutical firm raised the price of the drug from $\$ 3 /$ pill to $\$ 9 /$ pill. A second group assessed the ethicality of a different course of action:

B: The major pharmaceutical $\mathrm{X}$ sold the rights to a smaller pharmaceutical. In order to recoup costs, company $\mathrm{Y}$ increased the price of the drug to $\$ 15 /$ pill.

As Paharia et al. (2009) predicted, participants judged Action A more harshly than those who read Action B, despite the smaller negative impact of Action A on patients.

A very different and profound example of how we do not understand our own morality coms from the work of Jon Haidt and colleagues (Haidt, Koller, \& Dias, 1993; Haidt, 2001), who demonstrated that out intuitive, affective selves often drive our ethical behavior and judgments. For example, consider one of the scenarios used by Haidt in his research describing a situation where "a family's dog was killed by a car in front of their house. They had heard that dog meat was delicious, so they cut up the dog's body and cooked it and ate it for dinner." Haidt and his colleagues (Haidt et al., 1993; Haidt, 2001) presented this scenario and others (involving cleaning with the American flag, sex between siblings that creates no harm, among others) to study participants and the vast majority found the behavior described in the story to be morally wrong. Yet, they often can't immediately tell you why they think it is wrong, responding instead with statements such as "I don't know, I can’t explain it, I just know" (Haidt, 2001).

The results of this research suggest that affective reactions to these types of situations precede moral judgment. Haidt (2001) argues that our judgments are often driven by intuitive, emotional responses, and after such judgments are made, we engage in deliberate moral 
reasoning to justify our immediate reaction. This argument is in direct contradiction to the assumption that unethical behaviors derive from a deliberative process.

Finally, experimental philosophers are an important part of the existing work on bounded ethicality. Consider a well-known example from the work of Knobe (2009):

The chairman of a company has to decide whether to adopt a new program. It would increase profits and help the environment too. "I don't care at all about helping the environment," the chairman says. "I just want to make as much profit as I can. Let's start the new program."

Did the chairman intend to help the environment? Now consider the following situation:

The chairman, who again doesn't care about the environment, authorizes the program to improve profits. Profit goals are realized but the environment is negatively impacted.

In this case, did the chairman harm the environment intentionally?

In both scenarios, the chairman's only goal was to make money. Yet, we tend to judge his intention differently based on the consequences his decision had. When improvements to the environment occurred, only $23 \%$ of respondents in Knobe's (2009) study said that the chairman had intentionally helped the environment. In contrast, when harm occurred, $82 \%$ of respondents believed that the chairman had intentionally harmed the environment.

Together, these studies on bounded ethicality show how, as human beings, we often do not recognize the ethical issues involved in the decisions we are facing and the judgments we make about the behavior of others.

\section{Improving Ethics by Using a Behavioral Ethics Perspective}

We believe that the research reviewed in this paper has implications for ethics training and for the policy formation process. We discuss each below.

III.1 Changing Individual Morality 
Let's return to the trolley and footbridge problems that we mentioned in the beginning of this paper. As you may recall, study participants were much more likely to turn a switch (in the trolley problem) than to push (in the footbridge problem) a person in order to save five lives at the expense of one innocent bystander. The trolley problem induced utilitarian thinking, while the footbridge induced deontological thinking, for most people. What would more reflection on the problem lead to?

Cushman, Tsay, Greene, and Bazerman (current data collection) have explored this question by comparing how people make decisions either separately, evaluating one option at a time, or jointly, evaluating both options together (Bazerman, Loewenstein, \& White, 1992; Hsee et al., 1999). Cushman et al. changed the switch problem so that you would save three lives at the cost of one by choosing to switch. Still, $76 \%$ of the participants decided to switch. In the footbridge problem, where five lives were being saved, only $41 \%$ of the participants decided to push. Thus, when presented with one of these options, people were more willing to switch to save three lives than to push to save five. But, Cushman et al. went a step further and gave a separate group of study participants a problem in which two trains were coming down two different tracks. One track A, three people were about to die. On track B, five people were about to die. Participants could save the three by switching, save the five by pushing, or doing nothing. Now, study participants shifted toward being utilitarian. Only $18 \%$ switched to save three lives, while $45 \%$ pushed to save five. With more information and more clarity, utilitarian analyses became more dominant.

Similarly, Lee and Gino (2012) examined how people would respond to footbridge-type of scenarios when they are asked to suppress their emotions prior to considering the ethical dilemmas. Suppression involves concealing emotions after the initial emotional response has 
occurred. Lee and Gino (2012) argued that if moral decisions are influenced by both affective and cognitive forces, then the ability to regulate emotional reactions amidst moral dilemmas should be crucial in determining whether one is more or less likely to choose utilitarian options. Consistent with their arguments, Lee and Gino (2012) found that study participants who were instructed to suppress their emotions were more likely to choose the utilitarian option when faced with an ethical dilemma similar to the footbridge problem. Their results also demonstrated that the relationship between emotion suppression and utilitarian preference was stronger for those participants who had low emotional reactivity as assessed by psychophysiological responses.

We acknowledge that these types of trolley and footbridge problems may seem too removed from reality. So, it is useful to examine if the same kind of shift occurs in more realistic settings. Paharia et al. (2009), in their investigation of the drug price increase problem, presented a third group of participants with both possible actions simultaneously (i.e., Options A and B described earlier). They then asked this group of participants to judge which of the two actions was more unethical. In this case, preferences reversed. When participants could compare the two scenarios, they judged an indirect price increase to $\$ 15$ as more unethical than a direct price increase to $\$ 9$.

Why do these shifts occur? Behavioral decision research makes a distinction between System 1 and System 2 thinking that can be useful in understanding these inconsistencies in our moral preferences (Stanovich \& West, 2000; Kahneman \& Frederick, 2002). System 1 thinking is our intuitive decision making in action. It is fast, automatic, effortless, implicit, and emotional. System 1 is normal and efficient, and appropriate for the vast majority of decisions that you make on a daily basis. System 2 is what we do when we think in systematic and organized manner. This system is slower, conscious, effortful, explicit, and logical. 
System 1 thinking is comparatively more prevalent in separate, "one-at-a-time" decisions. In contrast, System 2 thinking is comparatively more prevalent in joint, "multiple option" decisions. People would like to trust their gut (System 1). And, System 2 thinking is certainly not required for every decision we make. In fact, System 1 is just fine for most decisions. For instance, it would not make sense to incur the costs of System 2 for every choice we make while shopping for groceries. But, System 2 logic should be used for more important decisions, and for decisions with ethical import. Yet, the frantic pace of many of our lives leads us to rely on System 1 thinking, even when System 2 thinking is warranted (Chugh, 2004). Mead et al. (2009) found that cognitively busy study participants were more likely to behave unethically than less cognitively busy study participants (for additional empirical support, see Gino et al., 2011). It takes cognitive energy to be reflective enough to stop the impulse to cheat.

The critical result from research on System 1 versus System 2 thinking, and from joint versus separate preference reversals is that shifting the modes of thought can lead to profound differences in how we make ethical decisions. This has implications at the individual and at the societal level. The decisions we make can create great harm. We certainly believe that there were some greedy actors involved in creating the recent financial crisis who engaged in clearly illegal and unethical behavior. But, we also need to address the behavior of thousands who contributed to the problem without realizing that they were doing anything wrong or who did not understand what situational and social pressures was leading them to move away from their moral compass. Greater awareness of behavioral ethics can help on that front.

\section{III.2 Changing Policy}

The designers of our institutions, our organizations and our government can intervene to change the way we see and react to problems. Thaler and Sunstein (2008) outline a structure of 
how to change institutions that take into account the most accurate expectations of how humans behave. This has important implication in policy formulation. We can require smart meters so that homeowners make wiser decisions. We can change the labels about gas mileage in vehicles to make them more informative to consumers at the point of purchase (Larrick \& Soll, 2008). By understanding how humans behave unethically both intentionally and unintentionally, we can intervene to design institutions and organizations that will lead to more ethical decisions.

Perhaps it is easiest to demonstrate the relevance of behavioral ethics to policy formulation by considering a specific policy domain. Based on our prior writing, we will overview policy formation in the area of auditing. The reason to create the role of auditing is to provide outside parties with an independent assessment of the financial condition of firms. Without independence, there is no reason to have the institution of an external auditing. As former Chief Justice Warren Burger noted:

The independent auditor assumes a public responsibility transcending any employment relationship with the client. The independent public accountant performing this special function owes ultimate allegiance to the corporation's creditors and stockholders, as well as to [the] investing public. This "public watchdog" function demands that the accountant maintain total independence from the client at all times and requires complete fidelity to the public trust.

Yet, the way in which auditing has emerged in our society makes it clear that auditors were not, and still are not, independent (Bazerman, Morgan, and Loewenstein, 1997). The threats to independence include auditors profiting by being rehired by their clients, auditors selling other services to their clients, and specific audit employees taking jobs with their present and former clients. In each case, a conflict of interest is created where auditors have a responsibility to be 
objective, and have financial interests in keeping the client happy. Consistent with decades of research in social psychology, each of these three conditions makes independence a farce. When human beings have a vested stake in seeing the data in a particular manner, even honest people are not cognitively capable of making an unbiased or independent assessment (Babcock \& Loewenstein, 1996).

In contrast, consider what most people, including policy-makers, think of when they reflect on the issue of conflict of interest. They think of the intentional choice between doing what is right versus doing what is in one's self-interest. Back in 2000, before Enron collapse, and before Sarbanes-Oxley was enacted, the SEC held hearings on whether consulting work by auditing firms compromised auditor independence. CEOs of three of the five large audit firms (the Big Five; now the Final Four after the collapse of Arthur Andersen) clarified that they were professionals who could be trusted. They presented the issue of conflict of interest as one of integrity, and argued that their need to maintain their reputation provided society with protection. While we personally question the integrity of these firms, the important issue is that if society and SEC understand that conflict of interest most commonly occurs implicitly, without the auditor even being aware that she is being affected by her incentives, we quickly see that integrity is no longer adequate protection. Just as we do not trust the most honest parent to assess the brilliance of their child, we should not trust auditors to be independent when they have vast psychological reasons to fail in their pursuit of objectivity. Rather, vast changes to our current auditing institutions are needed for auditors to provide the most basic requirement of their function - independence. A similar analysis applies to rating agencies, who played a critical role in the recent financial collapse. 
More broadly, we highlight that the analysis of public policies looks fundamentally different when we understand some of the basic aspects of how human beings act in morally relevant domains. As the assumption that individuals have control over their behavior has dominated policy making, we see that value-creating policy requires a more thorough understanding of behavior ethics.

The most important conclusion of the research on behavioral ethics, however, may be on how ethics is currently taught in professional schools. Rather than teaching students how they should behave when facing ethical dilemmas, or informing them about what philosophers would recommend, the behavioral ethics perspective suggests a different approach. Behavioral ethics sees an opportunity in helping students and professionals better understand their own behavior in the ethics domain, and compare it to how they would ideally like to behave. We believe that only by reflecting on their ethical failures and the inconsistencies between their desire to be moral and their actual behavior they can rise to the actions (and ethical standards) that their more reflective selves would recommend. 


\section{References}

Adams, J. S., Tashchian, A., \& Shore, T. H. 2001. Codes of ethics as signals for ethical behavior. Journal of Business Ethics, 29: 199-211.

Aquino, K., Felps, W. A., Lim, V. K. G., Freeman, D., \& Reed, A. I. I. 2009. Testing a socialcognitive model of moral behavior: The interactive influence of situations and moral identity centrality. Journal of Personality and Social Psychology, 97(1): 123.

Ayal, S., \& Gino, F. 2011. Honest rationales for dishonest behavior. In M. Mikulincer \& P. R. Shaver (Eds.), The Social Psychology of Morality: Exploring the Causes of Good and Evil. Washington, DC: American Psychological Association.

Batson, C. D., Kobrynowicz, D., Dinnerstein, J. L., Kampf, H. C., \& Wilson, A. D. 1997. In a very different voice: Unmasking moral hypocrisy. Journal of Personality and Social Psychology, 72(6): 1335-1348.

Batson, C. D., Thompson, E. R., \& Chen, H. 2002. Moral hypocrisy: Addressing some alternatives. Journal of Personality and Social Psychology, 83(2): 303-339.

Batson, C. D., Thompson, E. R., Seuferling, G., Whitney, H., \& Strongman, J. A. 1999. Moral hypocrisy: Appearing moral to oneself without being so. Journal of Personality and Social Psychology, 77(3): 525-537.

Bazerman, M. H., \& Banaji, M. R. 2004. The social psychology of ordinary ethical failures. Social Justice Research, 17: 111-115.

Bazerman, M., \& Moore, D. A. 2008. Judgment in Managerial Decision Making. Wiley, $7^{\text {th }}$ Edition.

Bazerman, M. H., \& Tenbrunsel, A. E. 2011. Blind spots: Why we fail to do what's right and what to do about it. Princeton University Press. 
Bazerman, M. H., Loewenstein, G. F., \& White, S. B. 1992. Reversals of preference in allocation decisions: Judging an alternative versus choosing among alternatives. Administrative Science Quarterly, 37(2): 220-240.

Bazerman, M. H., Tenbrunsel, A. E., \& Wade-Benzoni, K. A. 1998. Negotiating with yourself and losing: Making decisions with internal competing preferences. Academy of Management Review, 23(2): 225-241.

Bersoff, D. 1999. Why good people sometimes do bad things: Motivated reasoning and unethical behavior. Personality and Social Psychology Bulletin, 25: 28-39.

Brief, A. P., \& Motowidlo, S. J. 1986. Prosocial organizational behaviors. Academy of Management Review, 11: 710-725.

Chugh, D. 2004. Societal and managerial implications of implicit social cognition: Why milliseconds matter. Social Justice Research, 17(2): 203-222.

Chugh, D., Banaji, M., \& Bazerman, M. 2005. Bounded ethicality as a psychological barrier to recognizing conflicts of interest. In Moore, D., Cain, D., Loewenstein, G., \& Bazerman, M. (Eds.), Conflicts of Interest: Challenges and Solutions in Business, Law, Medicine, and Public Policy. New York: Cambridge University Press.

Cialdini, R. B, Reno, R. R., \& Kallgren, C. A. 1990. A focus theory of normative conduct: Recycling the concept of norms to reduce littering in public places. Journal of Personality and Social Psychology, 58: 1015-1026.

Cialdini, R. B., \& Trost, M. R. 1998. Social influence: Social norm, conformity, and compliance. In D. T. Gilbert, S. T. Fiske, \& G. Lindzey (Eds.). Handbook of social psychology (Vol. 2, pp. 151-192). New York: McGraw-Hill. 
Cushman, F., \& Young, L. 2012. Deriving moral principles from non-moral representations: A study of three distinctions. Cognitive Science.

Cushman, F. A., Dreber, A., Wang, Y., \& Costa, J. 2009. Accidental outcomes guide punishment in a 'trembling hand' game. PLOS One 4(8): e6699. doi:10.1371/journal.pone.0006699

Ferrell, O. C., Fraedrich, J., \& Ferrell, L. 2008. Business ethics: Ethical decision making and cases, 7th ed., Boston: Houghton Mifflin.

Foot, P. 1978. Virtues and vices. Oxford: Blackwell.

Gibbs, J. C., Basinger, K. S., \& Fuller, D. 1992. Moral maturity: Measuring the development of sociomoral reflection. Hillsdale, NJ: Erlbaum.

Gino, F., \& Ariely, D. 2012. The dark side of creativity: original thinkers can be more dishonest. Journal of Personality and Social Psychology. Forthcoming.

Gino, F. \& Bazerman, M. H. 2009. When misconduct goes unnoticed: The acceptability of gradual erosion in others' unethical behavior. Journal of Experimental Social Psychology, 45(4): 708-719.

Gino, F., \& Galinsky, A. 2012. Vicarious dishonesty: When psychological closeness creates distance from one's moral compass. Working paper.

Gino, F., Ayal, S., \& Ariely, D. 2009. Contagion and differentiation in unethical behavior: The effect of one bad apple on the barrel. Psychological Science, 20(3): 393-398.

Gino, F. \& Pierce, L. 2009. The abundance effect: Unethical behavior in the presence of wealth. Organizational Behavior and Human Decision Processes, 109(2): 142-155.

Gino, F., Moore, D. A. \& Bazerman, M. H. 2009. See no evil: Why we fail to notice unethical behavior. In R. M. Kramer, A. E. Tenbrunsel andM. H. Bazerman (Ed.), Social Decision 
Making: Social Dilemmas, Social Values, and Ethical Judgments (pp. 241-263).

Psychology Press.

Gino, F., Moore, D., \& Bazerman, M. H. 2012. No harm, no foul: Explaining the outcome bias in ethical judgments. Working paper.

Gino, F., Schweitzer, M., Mead, N., \& Ariely, D. 2011. Unable to resist temptation: How selfcontrol depletion promotes unethical behavior. Organizational Behavior and Human Decision Processes, 115(2): 191-203.

Gino, F., Shu, L. L., \& Bazerman, M. H. 2010. Nameless + Harmless = Blameless: When seemingly irrelevant factors influence judgment of (un)ethical behavior. Organizational Behavior and Human Decision Processes, 111(2): 102-115.

Greene, J. D. (2012). The moral brain and how to use it. Penguin Group, New York.

Haidt, J. 2001. The emotional dog and its rational tail: A social intuitionist approach to moral judgment. Psychological Review, 108: 814-834.

Haidt, J., Koller, S., \& Dias, M. 1993. Affect, culture, and morality, or is it wrong to eat your dog? Journal of Personality and Social Psychology, 65: 613-628.

Hsee, C. K., Loewenstein, G. F., Blount, S., \& Bazerman M. H. 1999. Preference reversals between joint and separate evaluations of options: A review and theoretical analysis. Psychological Bulletin, 125: 576-591.

Jones, T. M. 1991. Ethical decision making by individuals in organizations: An issue-contingent model. Academy of Management Review, 16(2): 366-395.

Jordan, J., Mullen, E., \& Murnighan, J. K. 2011. Striving for the moral self: The effects of recalling past moral actions on future moral behavior. Personality and Social Psychology Bulletin, 37: 701-713. 
Kahneman, D., \& Frederick, S. 2002. Representativeness revisited: Attribute substitution in intuitive judgment. In T. Gilovich, D. Griffin \& D. Kahneman (Eds.), Heuristics and biases: The psychology of intuitive judgment (pp.49-81). New York : Cambridge University Press.

Keizer, K., Lindenberg, S., \& Steg, L. 2008. The spreading of disorder. Science, 322: 1681-85.

Kern, M. \& Chugh, D. 2009. Bounded ethicality: The perils of loss framing. Psychological Science, 20(3): 378-384.

Knobe, J. 2009. Answers to Five Questions. In Aguilar, J \& Buckareff, A (eds.) Philosophy of Action: 5 Questions. London: Automatic Press.

Knobe, J. \& Nichols, S. 2008. Experimental philosophy. New York: Oxford University Press.

Knobe, J. 2003. Intentional action in folk psychology: An experimental investigation. Philosophical Psychology, 16: 309-324.

Kohlberg, L. 1981. Essays on Moral Development, Vol. I: The Philosophy of Moral Development. Harper \& Row.

Larrick, R. P., \& Soll, J. B. 2008. The MPG illusion. Science, 320: 1593-1594.

Lee, J. J., \& Gino, F. 2012. Who makes a tough call? Concealing emotions lead to utilitarian decision making. Working paper.

Loewenstein, G. 1996. Behavioral decision theory and business ethics: Skewed tradeoffs between self and other. In D. M. Messick and A. E. Tenbrunsel (Eds.). Codes of Conduct: Behavioral Research into Business Ethics, pp. 214-227. New York: Russell Sage Foundation.

Mazar, N., Amir, O., \& Ariely, D. 2008. The dishonesty of honest people: A theory of selfconcept maintenance. Journal of Marketing Research, 45: 633-644. 
Mead, N., Baumeister, R. F., Gino, F., Schweitzer, M., \& Ariely, D. 2009. Too tired to tell the truth: Self-control resource depletion and dishonesty. Journal of Experimental Social Psychology, 45(3): 594-597.

Messick, D. M. 1994. March 1. Mortgage-bias complexities. Chicago Tribune.

Messick, D. M., \& Bazerman, M. H. 1996. Ethical leadership and the psychology of decision making. Sloan Management Review: 9-22.

Messick D. M., \& Tenbrunsel, A. E. (Eds.). Codes of Conduct: Behavioral Research into Business Ethics. New York: Russell Sage Foundation.

Milgram, S. 1974. Obedience to authority: An experimental view. New York: Harper and Row.

Monin, B. 2007. Holier than me? Threatening social comparison in the moral domain. International Review of Social Psychology, 20(1): 53-68.

Monin, B., \& Jordan, A. H. 2009. Dynamic moral identity: A social psychological perspective. Chapter 15 (pp.341-354) in D. Narvaez \& D. Lapsley (Eds.), Personality, Identity, and Character: Explorations in Moral Psychology, Cambridge University Press.

Monin, B., \& Miller, D. T. 2001. Moral credentials and the expression of prejudice. Journal of Personality and Social Psychology, 81(1): 33-43.

Monin, B., Sawyer, P. J., \& Marquez, M. J. 2008. The rejection of moral rebels: Resenting those who do the right thing. Journal of Personality and Social Psychology, 95(1): 76-93.

Moore, D. A., Tetlock, P. E., Tanlu, L., \& Bazerman, M. H. 2006. Conflicts of interest and the case of auditor independence: Moral seduction and strategic issue cycling. Academy of Management Review, 31: 10-29. 
Nisan, M. 1991. The moral balance model: Theory and research extending our understanding of moral choice and deviation. In W. M. Kurtines \& J. L. Gewirtz (Eds.), Handbook of moral behavior and development (pp. 213-249). Hillsdale, NJ: Erlbaum.

Paharia, N., Kassam, K. S., Greene, J. D., and Bazerman, M. H. (2009). Dirty work, clean hands: The moral psychology of indirect agency. Organizational Behavior and Human Decision Processes, 109: 134-141.

Piovesan, M., \& Montinari, N., Gino, F., \& Norton, M. I. 2012. Usage of the veil of fairness develops over childhood. Working paper.

Pizarro, D., Inbar, Y., \& Helion, C. 2011. On disgust and moral judgment. Emotion Review, 3(3): $1-2$.

Posner, R. A. 1997. Against ethical criticism. Philosophy and Literature, 21(1): 1-27.

Rest, J. R. 1986. Moral development: Advances in research and theory. New York: Praeger.

Rest, J. R., \& Navarez, D. 1994. Moral development in the professions: Psychology and applied ethics. Hillsdale, NJ: Erlbaum.

Schulman, M. 2002. How we become moral. In C. R. Snyder, \& S. J. Lopez (Eds.), Handbook of Positive Psychology: 499-512. Oxford: University Press.

Schweitzer, M. E. \& Hsee, C. K. 2002. Stretching the truth: Elastic justification and motivated communication of uncertain information. Journal of Risk and Uncertainty, 25: 185-201.

Schweitzer, M., Ordonez, L., \& Douma, B. 2004. The role of goal setting in motivating unethical behavior. Academy of Management Journal, 47: 422-432.

Schwitzgebel, E. 2009. Do ethicists steal more books? Philosophical Psychology, 22: 711-725 
Shalvi, S., Dana, J., Handgraaf, M. J. J., \& De Dreu, C. K. W. 2011. Justified ethicality: Observing desired counterfactuals modifies ethical perceptions and behavior. Organizational Behavior and Human Decision Processes, 115: 181-190.

Shu, L. L., Gino, F., \& Bazerman, M. H. 2011. Ethical discrepancy: Changing our attitudes to resolve moral dissonance. In D. De Cremer and A. E. Tenbrunsel (Ed.), Behavioral Business Ethics: Ideas on an Emerging Field. Taylor and Francis Publishing.

Stanovich, K. E., \& West, R. F. 2000. Individual differences in reasoning: Implications for the rationality debate. Behavioral \& Brain Sciences, 23: 645-665.

Tajfel, H. 1982. Social identity and intergroup relations. Cambridge, England: Cambridge University Press.

Tajfel, H., \& Turner, J. C. 1986. The social identity theory of inter-group behavior. In S. Worchel and L. W. Austin (eds.), Psychology of Intergroup Relations. Chicago: NelsonHall.

Tenbrunsel, A. E., \& Smith-Crowe, K. 2008. Ethical decision making: Where we've been and where we're going. The Academy of Management Annals, 2(1): 545-607.

Tenbrunsel, Diekmann, Wade-Benzoni, \& Bazerman, 2011

Thaler, Richard H., and Cass R. Sunstein, Nudge: Improving Decisions about Health, Wealth, and Happiness (New Haven, CT: Yale University Press, 2008).

Thomson, J. J. 1976. Killing, letting die, and the trolley problem. The Monist, 59: 204-217.

Treviño, L. K. 1986. Ethical decision making in organizations: A person-situation interactionist model. Academy of Management Review, 11(3): 601-617.

Treviño, L.K. \& Weaver, G. 1994 Business ETHICS/BUSINESS ethics: One field or two? Business Ethics Quarterly, 4: 113-28. 
Treviño, L. K., Weaver, G. R., \& Reynolds, S., 2006. Behavioral ethics in organizations: A review. Journal of Management, 32(6): 951-990.

Turner, J. C. 1982. Toward a cognitive redefinition of the social group. In H. Tajfel (Ed.), Social identity and intergroup behavior (pp. 15-40). Cambridge, England: Cambridge University Press.

Uhlmann, E. L., Pizarro, D. A., Tannenbaum, D., \& Ditto, P. H. 2009. The motivated use of moral principles. Judgment and Decision Making, 4: 479-491.

Wade-Benzoni, K. A. 1999. Thinking about the future: An intergenerational perspective on the conflict and compatibility between economic and environmental interests. American Behavioral Scientist, 42: 1393-1405.

Weaver, G. R. 2001. The role of human resources in ethics/compliance management: A fairness perspective. Human Resource Management Review, 11(1-2): 113.

Zhong, C., Bohns, V. K., \& Gino, F. 2010. A good lamp is the best police: Darkness increases self-interested behavior and dishonesty. Psychological Science, 21(3): 311-314.

Zimbardo, P. 1969. The psychology of evil: A situationist perspective on recruiting good people to engage in anti-social acts. Research in Social Psychology, 11: 125-133. 


\section{Figure Captions}

Figure 1. The trolley dilemma

Figure 2. The footbridge dilemma

Figure 3. An example of the add-to-ten problem solving task 


\section{Tables}

Table 1. Definition of ethical behavior or behavioral ethics provided in the literature

\begin{tabular}{|c|c|c|}
\hline Construct & Definition & Source \\
\hline Behavioral ethics & $\begin{array}{l}\text { Study of individual behavior that is subject } \\
\text { to or judged according to generally } \\
\text { accepted moral norms of behavior }\end{array}$ & $\begin{array}{l}\text { Trevino, Weaver, \& Reynolds, } \\
2006 \text { (p. 952) }\end{array}$ \\
\hline Behavioral ethics & $\begin{array}{l}\text { Behavioral ethics is primarily concerned } \\
\text { with explaining individual behavior that } \\
\text { occurs in the context of larger social } \\
\text { prescriptions }\end{array}$ & $\begin{array}{l}\text { Tenbrunsel \& Smith-Crowe, } \\
2008 \text { (p. 548) }\end{array}$ \\
\hline Moral behavior & $\begin{array}{l}\text { Acts intended to produce kind and/or fair } \\
\text { outcomes }\end{array}$ & Schulman, 2002 (p. 500) \\
\hline Moral behavior & $\begin{array}{l}\text { Actions that demonstrate social } \\
\text { responsiveness to the needs and interests } \\
\text { of others }\end{array}$ & $\begin{array}{l}\text { Aquino, Freeman, Reed, Lim, } \\
\& \text { Felps, } 2009 \text { (p. 124) }\end{array}$ \\
\hline Ethical decision & $\begin{array}{l}\text { A decision that is both legally and morally } \\
\text { acceptable to the larger community }\end{array}$ & Jones, 1991 (p. 387) \\
\hline $\begin{array}{l}\text { Moral and amoral } \\
\text { decision making }\end{array}$ & $\begin{array}{l}\text { - They suggest that within each class of } \\
\text { decisions, one can make ethical decision or } \\
\text { unethical decisions. } \\
\text { - They argue that social scientist should } \\
\text { not be in the business of telling people } \\
\text { what they should do, that is define what is } \\
\text { ethical and what is not, but they do } \\
\text { acknowledge the necessity to define the } \\
\text { criteria by which decisions are placed into } \\
\text { their typology for analytical purposed. }\end{array}$ & $\begin{array}{l}\text { Tenbrunsel \& Smith-Crowe } \\
\text { (2008) }\end{array}$ \\
\hline Ethical fading & $\begin{array}{l}\text { The process by which the moral colors of } \\
\text { an ethical decision fade into bleached hues } \\
\text { that are void of moral implications }\end{array}$ & $\begin{array}{l}\text { Messick \& Tenbrunsel, } 2004 \\
\text { (p. 124) }\end{array}$ \\
\hline
\end{tabular}




\section{Figures}

Figure 1.

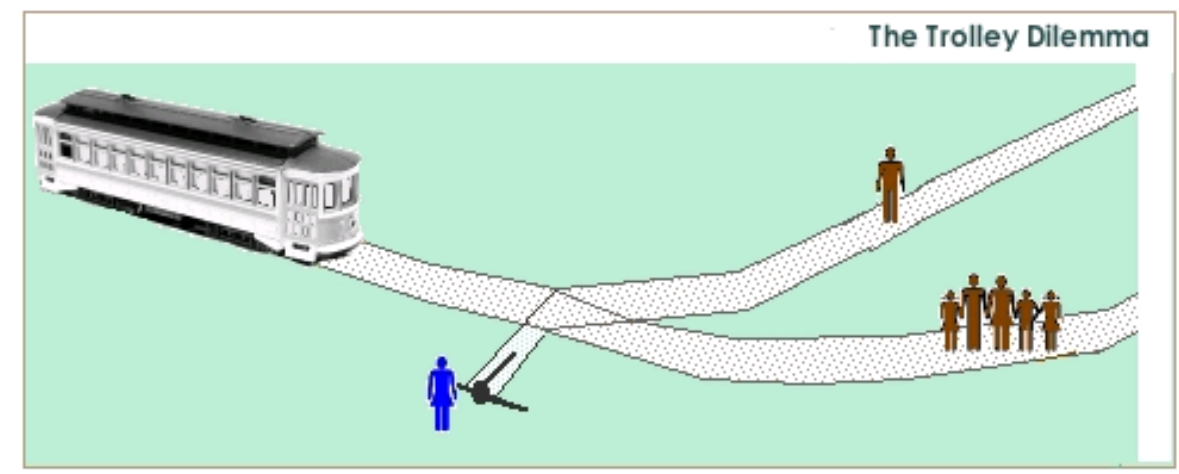

Figure 2.

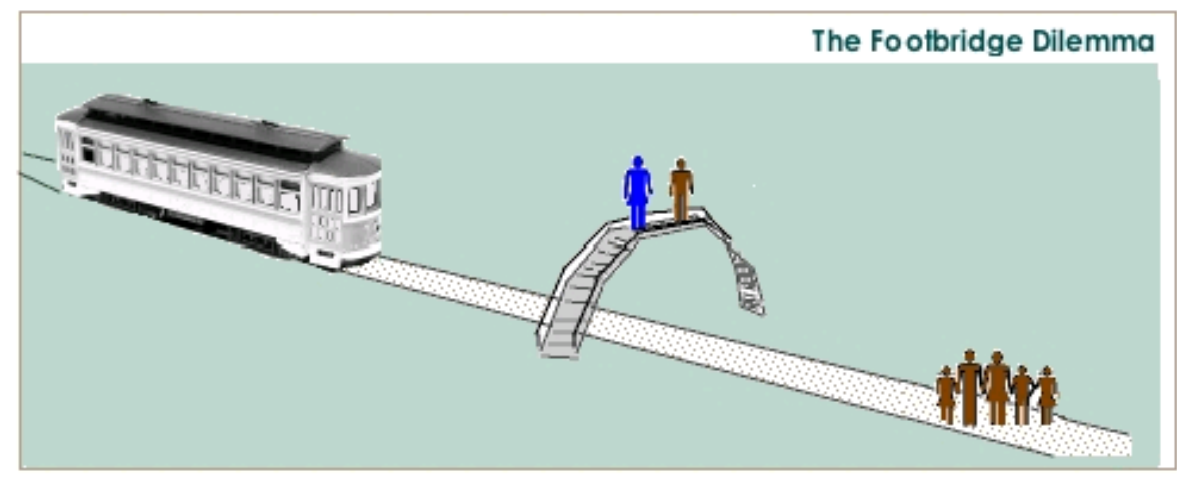

Figure 3.

\begin{tabular}{||c|c|c||}
\hline 8.19 & 6.46 & 1.62 \\
\hline 8.29 & 2.91 & 2.03 \\
\hline 2.73 & 7.89 & 9.86 \\
\hline 6.21 & 3.54 & 3.18 \\
\hline \multicolumn{3}{|c|}{ Found it } \\
\hline
\end{tabular}

